\title{
LUDICIDADE: O JOGO E A BRINCADEIRA NA LINGUAGEM DA DANÇA
}

\section{Mariana Marques Kellermann}

\section{RESUMO}

Este artigo propõe reflexão sobre a importância do desenvolvimento psicomotor no ensino-aprendizagem da dança, seja nos conteúdos apresentados pela escola formal, seja nas escolas de dança que se interessam pelos estudos da percepção corporal e por seu desenvolvimento lúdico como fio condutor para a compreensão de um ser integrado. O objetivo é mapear jogos e brincadeiras surgidos da intensidade e da espontaneidade nas aulas de dança com crianças de 7 a 9 anos de idade que pretendiam ingressar em Cursos de Formação para Bailarinos na Escola de Teatro e Dança da Universidade Federal do Pará (ETDUFPA) em 2003, na cidade de Belém do Pará.

Palavras-Chave: Educação lúdica. Corpo. Dança. Movimento.

\begin{abstract}
This article proposes a reflection towards the importance of the psychomotor development in the teaching/learning of dance, be it in the regular school curricula or in the dance schools interested in body perception and its ludic development as guidance to the understanding of an integrated being. The objective is to map games and plays springing from the intensity and spontaneity in dance classes with 7-to-9 year old children, who intended to enter training courses for ballet dancers at the Federal University of Pará's Drama and Dance School (ETDUFPA) in 2003, Belém city, state of Pará.
\end{abstract}

- Bacharel em

Direito, pela

Universidade

Federal do Pará

(UFPA, 1977),

Atriz/Bailarina,

Professora do

Curso Técnico de

dança, Interprete-

Criador

(ETDUFPA),

Curso de

Licenciatura

em Dança

da (UFPA),

Especialista na

Consciência

Corporal/Dança

(FAP/PR , 1999),

Msc. nas Artes

Cênicas (UFBA),

Doutora nas Artes

Cênicas (UFBA),

Coordenadora/

Keywords: Edutainment; Body; Dance; Movement. 


\title{
1 AS JUNIANAS E SUAS BRINCADEIRAS: RITMO E HISTÓRIA PARA AS INTERPRETAÇÕES
}

\begin{abstract}
As festas juninas simbolizam o imaginário coletivo da sociedade. É uma forma de as pessoas se sentirem participantes de uma mesma comunidade emocional. É como se a pessoa estivesse celebrando o prazer daquele pertencimento, daquela maneira de sentir que é comum a todos.
\end{abstract}

João de Jesus Paes Loureiro (2011)

Existem versões que apontam a origem da festa junina em países católicos da Europa. No princípio, a festa era chamada de joanina, pois estava ligada ao nascimento de João Batista no dia 24 de junho. Segundo o relato bíblico, Isabel, prima de Maria (Nossa Senhora), ao saber que estava esperando um bebê, foi ao seu encontro para contar-lhe a boa nova. Seu bebê se chamaria João Batista. Todavia, Maria quis saber como faria para ser avisada quando a criança tivesse nascido. Naquele tempo, sem muita opção de comunicação, combinaram que o sinal de comunicação do nascimento seria uma fogueira. Lá de longe, Nossa Senhora avistou a fumaça e logo depois viu a fogueira. Ela então sorriu e, compreendendo a mensagem, foi visitá-la. Encontrou-a com um belo bebê nos braços e assim começou a ser festejado o dia de São João, com mastro, fogueira, foguete, muita dança e muita comida.

Para nós, brasileiros, a festa junina chegou por intermédio dos portugueses ainda durante o período colonial. Nessa época, havia grande influência de elementos culturais portugueses, chineses, espanhóis e franceses. E dos franceses é que deriva a quadrilha. Embora constantemente renovada, não se perde de sua origem francesa, basta ver, como diz Loureiro (2011), sua evolução coreográfica repleta de palavras da língua francesa como anarriê e avancê. Também de lá veio a grande influência das danças marcadas. Já a tradição de soltar fogos veio da China, região onde teria surgido a manipulação da pólvora para a fabricação de fogos. Da Península Ibérica teriam vindo as danças das fitas, muito comuns em Portugal e na Espanha. Esses elementos culturais foram se misturando com os elementos culturais indígenas, africanos e europeus, nas diversas regiões do país, tomando características particulares em cada uma delas.

Em Belém, a festa junina, por muito tempo, era comemorada nos terreiros e lá encontrávamos as fogueiras feitas de tora de madeira, geralmente muito grande. Em sua volta, faziam-se juras de amizade, anunciavam ser madrinha ou padrinho de 
alguém. As quadrilhas iam se apresentando e assim as casas em volta do terreiro (de chão batido, de terra) iam oferecendo as comidas e as bebidas. Hoje, nas ruas de Belém, mais desenvolvidas, não se pode mais ter a fogueira, ou seja, somente faz-se de conta que a fogueira está acesa e penduram-se as bandeirinhas de plástico.

\subsection{A coreografia: as junianas e suas brincadeiras}

A partir do processo criativo desenvolvido com as alunas da Oficina do Preparatório de Dança da ETDUFPA, selecionei alguns movimentos experimentados por elas com os exercícios ministrados em sala de aula, para a montagem de As Junianas e suas brincadeiras. Iniciei os trabalhos pedindo que as alunas se dividissem em grupo e que cada grupo utilizasse os brinquedos escolhidos por elas no jogo de identificação de objetos.

A divisão foi assim disposta: grupo de três meninas ficou com as marionetes do boi-bumbá e uma das meninas era a Catirina (personagem dessa história). Devido a essa divisão, achei importante abrir um precedente na aula para contar para as alunas, com ajuda de suas mães, a história do boi-bumbá, ou bumbá-meu-boi e quem era Catirina.

Desta vez, foi a avozinha de uma das meninas que nos deu a honra de contar essa história. Entretanto, senti necessidade de contar para as alunas que o boi-bumbá é uma dança dramática e que está presente em várias de nossas festividades como no Natal e nas festas juninas e que tem características diferentes recebendo, inclusive, denominações distintas de acordo com a localidade em que é apresentado. No Piauí e no Maranhão, chamam-no bumba-meu-boi; na Amazônia, boi-bumbá; em Santa Catarina, boi de mamão; no Recife, ele é o boi-calemba; e no Estado do Rio de Janeiro, é conhecido como folguedo do boi.

No embalo dessas informações, vovozinha começou a contar a história. Assim começou a narrar:

Catirina era uma mulher que esperando bebê sentiu uma vontade incontrolável de comer a língua do boi. Seu marido, pai Francisco, resolveu atender ao desejo da mulher e matou o primeiro boi que encontrou. Logo depois o dono do boi apareceu e ficou muito aborrecido ao ver seu animal ali, estendido, inerte, morto.

Segundo a vovozinha, para sorte de pai Francisco, aparece um curandeiro que ressuscita o boi e, aí, então, a partir desse momento, todo mundo ficou muito alegre e começou a dançar.

Essa história serviu para que as alunas fossem imaginar (depois de tirarem 
suas dúvidas sobre o boi-bumbá), uma história para contar com suas marionetes e sua Catirina (personagem vivido por uma aluna do grupo de três). Outras duas meninas formaram o grupo "anjos caipiras", que tinha como objeto cênico cestos de vime (que suas mães enfeitaram à moda caipira do Estado do Pará, com muitas fitas coloridas e patchouli), para transportar folhas secas que elas espalhavam pelo espaço do palco. Esse era o grupo que iniciava a coreografia.

Um terceiro grupo foi formado por mais seis alunas - "grupo das rosas", que surgiu num laboratório em que as alunas utilizaram rosas de papel crepom como objeto cênico. Finalmente, eu e uma de minhas alunas assistentes formamos o $4^{\circ}$ grupo e fizemos o grupo das "varas das fitas".

\section{Foto 1 - Alunas dançando a quadrilha: As Junianas e suas brincadeiras}

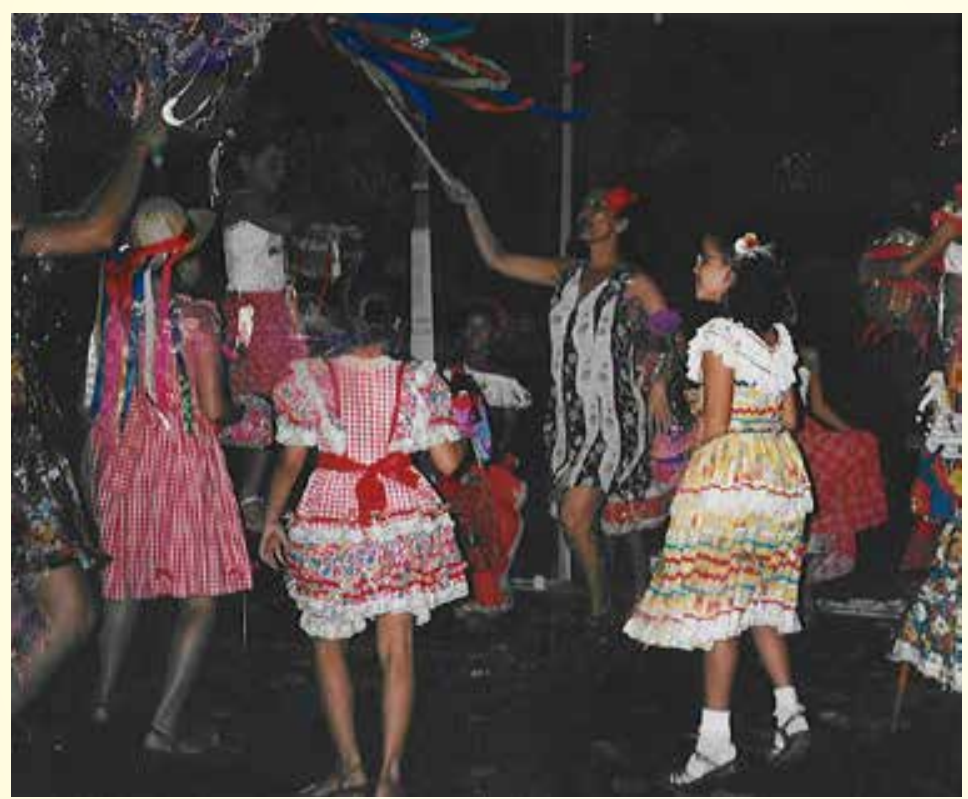

Fonte: Fotografia da autora, 2003

\subsection{0 roteiro}

A cena começava com duas cadeiras no palco e quando os anjos caipiras invadiam o espaço, andando solenemente enquanto espalhavam as folhas pelo chão que caíam flutuantes, eles subiam nas cadeiras e continuavam a jogar folhas que, no plano alto, faziam suas evoluções até cair no chão. Costurando a cena, entrava o grupo de duas meninas que, entre a fumaça do palco, tornavam-se figuras oníricas, dando à cena um sentido de sonho. Cada uma dessas caipiras levava um boi-bumbá na mão enquanto que a terceira componente andava em serpentina, em volta das 
dançarinas do boi e, com movimentos frenéticos, representava o desejo de Catirina de comer a língua do boi. Seus corpos eram a extensão do objeto cênico, ou seja, emprestavam seus movimentos para os bailados dos bois, o que causava a impressão que juntos flutuavam.

O "grupo das rosas" (de papel crepom em variadas cores) se movimentava em andadas, atravessava o palco, aproximando de seus corpos seus objetos cênicos, num ponto próximo, para depois continuar andando pelo espaço, afastando-se à procura de um ponto bem distante do primeiro experimentado e, com isso, entrelaçava-se à cena. Por fim, entrava o grupo das varas de fitas, nos colocando cada uma de um lado do espaço, proporcionando com isso que as alunas pudessem nos ver e continuassem plenas em suas criações, em suas invenções, em suas brincadeiras.

A nossa coreografia (minha e de minha aluna-assistente) entrava no palco para fechar o círculo da dança, ou seja, éramos as últimas. A música era de São João, mas não dançávamos em seu ritmo, não o seguíamos, era como se fosse um ritmo de fundo, ritmo/ambiente. Faziam as alunas seus ritmos individualizados, entre saltitos, saltados, girados, intercalando seus deslocamentos entre movimentos leves e flutuantes e muitas vezes arriscando uma pausa (que elas chamavam estátua), para que as outras que estavam também em cena pudessem passar entre seus corpos ali pausados com seus bois-bumbás em movimentos sinuosos, como numa reza que culminava com nossas varas coloridas que marcavam um ponto fixo no espaço e quando se deslocavam, criavam a cada passo um novo espaço.

\subsection{Critérios avaliativos dos ensaios e da coreografia}

Para a culminância do projeto, organizei ficha analítica com critérios avaliativos no que diz respeito à sociabilidade e disciplina durante os ensaios, na hora do espetáculo e após o mesmo. Concluí, por meio de observações, que no momento da coreografia as alunas mantiveram-se calmas e concentradas. No que diz respeito à orientação espacial, as alunas demonstraram segurança ao atravessar o espaço do palco, demonstrando que entendiam o que estavam interpretando e puderam curtir as marcas coreográficas num jogo harmônico, num jogo de alegria, num jogo espelho.

Quanto à preparação física apresentada em sala de aula para o desenvolvimento da coreografia, ela proporcionou o aporte fisiológico necessário. Com as atividades lúdicas, que eram compostas de muitas brincadeiras, as alunas 
demonstravam que sentiam grande prazer em dançar a quadrilha, pois a maioria já havia dançado esse ritmo em suas escolas, todavia, a novidade da quadrilha em questão ficou por conta do uso dos brinquedos (que considero, objetos cênicos), havendo, dessa forma, uma explosão de espontaneidade em termos de jogos e brincadeiras.

O trabalho coreográfico, por ter sido explorado por meio de jogos e brincadeiras, desenvolveu o relacionamento do grupo, a segurança, a confiança e, principalmente, o sentimento de cooperação. Acredito que devido a isso o grupo conseguiu dançar com mais desenvoltura e viveu com mais plenitude a experiência de apresentar-se ao público com uma coreografia.

No caminhar de meus experimentos e descobertas, observei que muitas vezes durante o ensaio se houvesse muita repetição das células coreográficas, diminuía a energia que deveria fazer-se presente na hora do jogo, dando lugar ao desinteresse. Reflexões feitas depois que terminei de trabalhar com as alunas no primeiro semestre de 2003 fizeram-me compreender o quanto é importante permanecer com o jogo até que o interesse se mostre pelos praticantes (SPOLIN, 2010), como, também, compreendi a importância de se trabalhar com o jogo corporal do aluno, de relacioná-lo com o espaço, estimular o jogo com o outro, para principalmente perceber o outro. Segundo Ramos (2007, p.53), "por meio dos jogos faz-se que as pessoas não passem pela vida sem notar que existe um espaço que é ao mesmo tempo limitado e amplo".

Em sala de aula, deveria desfazer-me daquela velha forma de ensinar, de aprender, da relação professor-aluno, pois passei a perceber que é muito mais importante ser parceira na experiência. Segundo Spolin (2010, p.27), “insistir muito na apresentação mata a vitalidade do jogo e provoca perguntas ansiosas". Muitas alunas ficavam perguntando: "como vamos fazer isso professora?". Comecei a perceber que também não era muito interessante contar como fazer e sim tomar a iniciativa de fazer, ou seja, de experimentar. Pensando assim, passei a analisar e construir os dados que foram se arquitetando e com os resultados organizei nova oficina para continuar desenvolvendo a percepção corporal das crianças que haviam se matriculado na oficina para que no ano seguinte pudessem ser distribuídas em sala de aula do Curso Experimental de Formação para Bailarino da ETDUFPA.

Como primeiro passo a dar nessa direção, pensei sobre não trazer mais aulas prontas de minha casa, pois conclui com as observações diagnosticadas que foi muito importante perceber as crianças no dia-a-dia da sala de aula e, dessa forma, 
compreender como trabalhar cada obstáculo encontrado, mudando o já planejado para em seguida apontar e trabalhar a necessidade apresentada pelo grupo.

Compartilho com as ideias de Spolin (2010) de que é por meio do aumento da capacidade de experimentar livremente que as potencialidades afloram. Argumenta também o autor que o estimulador desse processo é quem deve possibilitar ao aluno de dança descobrir seu movimento, sua presença, sua coreografia, sua dança. Pensando nisso, selecionei os seguintes jogos para que as alunas pudessem desenvolver as atividades lúdicas e finalmente mostrar os efeitos que causaram a prática dessas atividades em seus desenvolvimentos corporal e artístico.

Seguidamente descrevo e comento alguns jogos selecionados.

\section{O PROCESSO JOGO/DANÇA}

A criatividade infantil é uma semente que contém em si tudo o que o adulto vai realizar.

Fayga Ostrower (1987)

A conscientização do movimento, por meio da busca da corporeidade consciente do ser humano, possibilita a quem a pratica tornar-se mestre de si mesmo. Sua principal função é direcionar com estímulos diretos, esse autoconhecimento para que cada um descubra, por si só, todas as possibilidades.

Ramos (2007)

A partir da diagnose do estudo, conclui que as crianças em questão deveriam desenvolver atividades lúdicas mais específicas e assim resolvi continuar a aprofundar os jogos que foram selecionados da prática do primeiro semestre, pois a revisão serviu para que compreendesse que ali se abriu mais uma oportunidade de introduzir criteriosamente a ludicidade em meus conhecimentos como docente; sendo que dessa vez o carro-chefe para a tarefa de continuar estudando o corpo foi mais precisamente entender o que as atividades lúdicas poderiam possibilitar em termos de percepção corporal. As alunas deveriam mostrar com seus gestos os efeitos deixados pelas práticas dessas atividades e, dessa forma, como diz Luckesi (2000), mostrar em suas ações como está se construindo para seu desenvolvimento integral.

Pensando assim, uni ao conhecimento do movimento jogos que permitissem ao aluno sentir-se inteiro na atividade e pudesse cada vez mais criar espontaneamente, selecionando para aquele momento os jogos teatrais, baseados na metodologia de Spolin (2010), os quais contribuíram para o aumento da percepção corporal, para o desenvolvimento motor e para descobertas de habilidades e de possibilidades. Não estou dizendo que seja regra, mas acredito que sejam os jogos 
teatrais excelentes colaboradores para desenvolver a rapidez de raciocínio, instigando o aluno a encontrar soluções rápidas para situações que se apresentam e também por acreditar serem descobertas que as crianças levariam para vida toda (SPOLIN, 2010).

Mantive também incluídos nas práticas desse período os exercícios do Sistema Laban/ Bartenieff, visto que os preparatórios e os seis básicos (os Fundamentos Corporais Bartenieff), segundo Fernandes (2002), são exercícios, que além de

conscientizarem o praticante de sua postura, facilitam a movimentação, melhoram a expressão corporal em diversas técnicas de dança e de teatro. Facilitam na experimentação para a composição coreográfica, trabalham o desenvolvimento neurofisiológico (preventivo e curativo), fisioterapia e dançaterapia (FERNANDES, 2002, p. 58);

Continuei utilizando a improvisação ${ }^{1}$ como processo de criação, no sentido de fomentar as investigações das alunas, delas com elas próprias, dando-lhes a oportunidade de experienciar uma movimentação fruto de suas criações, o que me oportunizou entender como se apresentava a capacidade de cada uma delas de interiorizar ${ }^{2}$.

Obedecendo aos resultados da avaliação diagnóstica obtida na prática do primeiro semestre de 2003, selecionei os seguintes jogos para serem desenvolvidos como atividades lúdicas no segundo semestre do mesmo ano.

\subsection{Jogo da brincadeira com a respiração}

\section{Objetivos:}

Favorecer o contato da criança com a sua respiração (entendimento da inspiração e expiração);

Estimular com esse procedimento o conhecimento da criança sobre seu próprio corpo - segmento corporal, eixo corporal, parte dura (ossos), parte mole (músculos).

\section{Foco:}

Respiração como fio condutor para iniciar as atividades de sala de aula.

\section{Descrição:}

O exercício era feito com a criança inicialmente deitada no chão pronunciando as vogais. Cada vogal era colocada em uma parte do corpo, sendo a vogal I colocada no centro da cabeça, a vogal E colocada na garganta, a vogal A no tórax, a vogal $\mathrm{O}$ no centro do corpo e a vogal U na genitália. Para cada respiração, a

Como possibilidades de mais descobertas de como mover o corpo. Acredito que por ter iniciado meus conhecimentos como bailarina na dança moderna, sabia da importância da improvisação em dança, principalmente quando se pensa em mostrar a diferença de se mover o corpo em uma dança clássica e como se pode movêlo em outros tipos de dança, ou seja, aprendi como aluna de dança moderna que nos treinamentos a improvisação é amplamente utilizada durante $o$ processo de criação e de conscientização corporal e possibilita a criatividade e a criação. do seu corpo todo e das partes que o compõem. 
criança deveria ir associando uma vogal com uma parte de seu corpo. Tal exercício faz parte do Sistema Laban/Bartinieff (2002) que tem a respiração como suporte para o movimento corporal.

\section{Comentários sobre a vivência do jogo:}

No primeiro momento do exercício, o foco estava na movimentação do fluxo da respiração e, por isso, nas primeiras aulas com o treinamento da respiração, comecei chamando atenção das crianças para o movimento do ar, fazendo-as experimentar o ar que entra (inspiração) e o ar que sai (expiração), cuidando para que elas tomassem consciência do ato da respiração. Para as aulas seguintes introduzi o jogo respiratório. Para isto, iniciei o jogo pedindo que todas as alunas estivessem sentadas no chão e repetissem juntas as vogais. Nas primeiras aulas, comecei pelas as vogais I e E.

Mostrava às alunas que se colocassem suas mãos na cabeça perceberiam a vibração da vogal I. Fiz o mesmo processo com a letra E e pedi que colocassem suas mãos em suas gargantas e sentissem a vibração de tal vogal. Na aula seguinte, ainda sentadas, passei a percepção dessas alunas para as vogais A - que fica em torno do tórax - e da vogal O. Pedi que colocassem suas mãos em torno do abdômen. Em seguida, solicitei que exercitassem a vogal $U$ na região da genitália. Nas aulas seguintes, iniciaram a experimentação da respiração deitadas no chão e assim fui, ao longo do treinamento, estimulando a consciência respiratória até chegar na posição em pé.

Os exercícios respiratórios tornaram-se uma brincadeira entre as alunas que, por sua vez, associaram o som produzido pelas vogais a uma música. Esses exercícios passaram a fazer parte do aquecimento das aulas, pois observei que com a sua feitura as alunas acordavam seus corpos trazendo-os para o presente, colocandoos aptos para a aula que iria se iniciar, aumentando com isso a concentração e a energia corporal. Com a respiração, a consciência corporal das alunas era estimulada inundando seus corpos, preenchendo-o de vitalidade, tornando-as mais perceptivas no que diz respeito às sensações geradas em seu espaço interno.

Respirar através das vogais significa sentir sensações diferentes e, por isso, a cada aula era feito o exercício de maneira diferente. A prática do exercício, inicialmente, foi feita individualmente. Depois as alunas passaram a praticar em pares em que uma dizia a vogal e a outra experimentava (com a mão, ou outras partes do corpo) a vibração da vogal pronunciada, ao mesmo tempo, que tomava conhecimento das partes do corpo através do toque. 
Conforme foi avançando o conhecimento sobre o corpo e a respiração, as alunas também praticavam a respiração caminhando pelo espaço e finalmente alternando a letra e as observações das partes do corpo. Entretanto, observei que a maioria das alunas respirava muito forte e com isso inflava em demasia o pulmão fazendo com isso o levantamento dos ombros. Praticava a respiração com muita força, e a expiração era feita bruscamente, fazendo com que o ar saísse muito rapidamente do pulmão e não conseguisse sentir a relação entre a contração do abdômen, impulso do diafragma e pressão aérea pulmonar dinamizada.

Segundo Martins (2008), se há impulsos muito fortes no abdômen, ocorre uma pressão aérea subglótica fortíssima que gera ataques vocais bruscos ${ }^{3}$. Ao longo do estudo e devido às observações feitas, passei a trazer a carta do Sistema Locomotor $^{4}$ que possibilitou as alunas a observarem como a respiração ia se deslocando internamente por seus corpos, como também, a entender suas anatomias e fisiologias corporais, como, por exemplo, perceberem e imaginarem o movimento que faziam com a inspiração e a expiração, ou seja, como entrava e saia o ar de seus pulmões e onde se localizavam.

Por se tratar de um estudo longitudinal (ter trabalhado um único grupo durante oito meses), tive oportunidade de perceber que o importante para as alunas não era somente entender sua fisiologia pelo plano mental e sim que se possibilitasse por meio dos exercícios respiratórios perceberem por si só as harmonias de suas dinâmicas fisiológicas (MARTINS 2008). Com esse estudo, pude observar que as alunas tomaram consciência de suas partes do corpo e passaram também a observálas e relacioná-las com o espaço ao redor.

Lembro-me de que em uma das discussões finais da aula uma aluna disse: "tia, minha cabeça parece uma bola de jogar futebol, e é muito pesada", outras perceberam tocando o corpo da colega que o corpo é feito de partes duras (músculos) e moles (articulações) e que os ossos que compõem o esqueleto são uns longos outros curtos. Percebi com essa prática que em qualquer idade conciliar respiração e movimento é muito difícil e que a solução talvez, seja estimular a concentração, liberando a respiração, deixando-a fluir de acordo com a resposta sinestésica do movimento. Segundo Fernandes (2002), o ator-bailarino (no caso deste estudo, o aluno de dança)

na inspiração se prepara para o movimento, expandindo e permitindo a respiração profunda. $\mathrm{Na}$ expiração, usa o diafragma para engajar o Iliopsoas e o Quadrado Lombar numa Corrente de Movimento até os músculos profundos do quadril. Esse suporte facilita toda transferência de

3 Segundo a autora, ataque vocal brusco, ou golpe de glote, acontece quando os sons iniciados são tão bruscos que ocorre uma contração abrupta dos músculos adutores da vibração da prega vogal (MARTINS, 2008, p.26).

${ }^{4}$ Mapa anatômico que apresenta o esqueleto. Apresentei esta carta para que as alunas pudessem perceber por onde se processava a respiração feita com as vogais $(A, E, I, O$, $\mathrm{U})$ e começassem a pensar suas anatomias corporais. 
peso corporal, desde a simples flexão coxofemoral até a mudança de nível sentando, levantando, caminhando, interagindo com o espaço tridimensional e de volta ao chão (FERNANDES, 2002, p. 41).

O jogo de brincar com a respiração também possibilitou, com o uso da vogal A, estimular nas alunas o entendimento de que o corpo se divide em membros superiores e inferiores e que eles podem se mover independente um do outro, ou podem se mover ao mesmo tempo (Foto 2) como se fosse um bloco. Isso contribuiu para que as alunas passassem a ter mais cuidado com o corpo do outro e os toques serviram para estabelecer entre elas afetividade e respeito pelo manejo do corpo do outro. Descobriram que a letra A é capaz de comandar a sonorização dos membros superiores com os inferiores e que cada uma tem seu modo próprio de provocar esta movimentação.

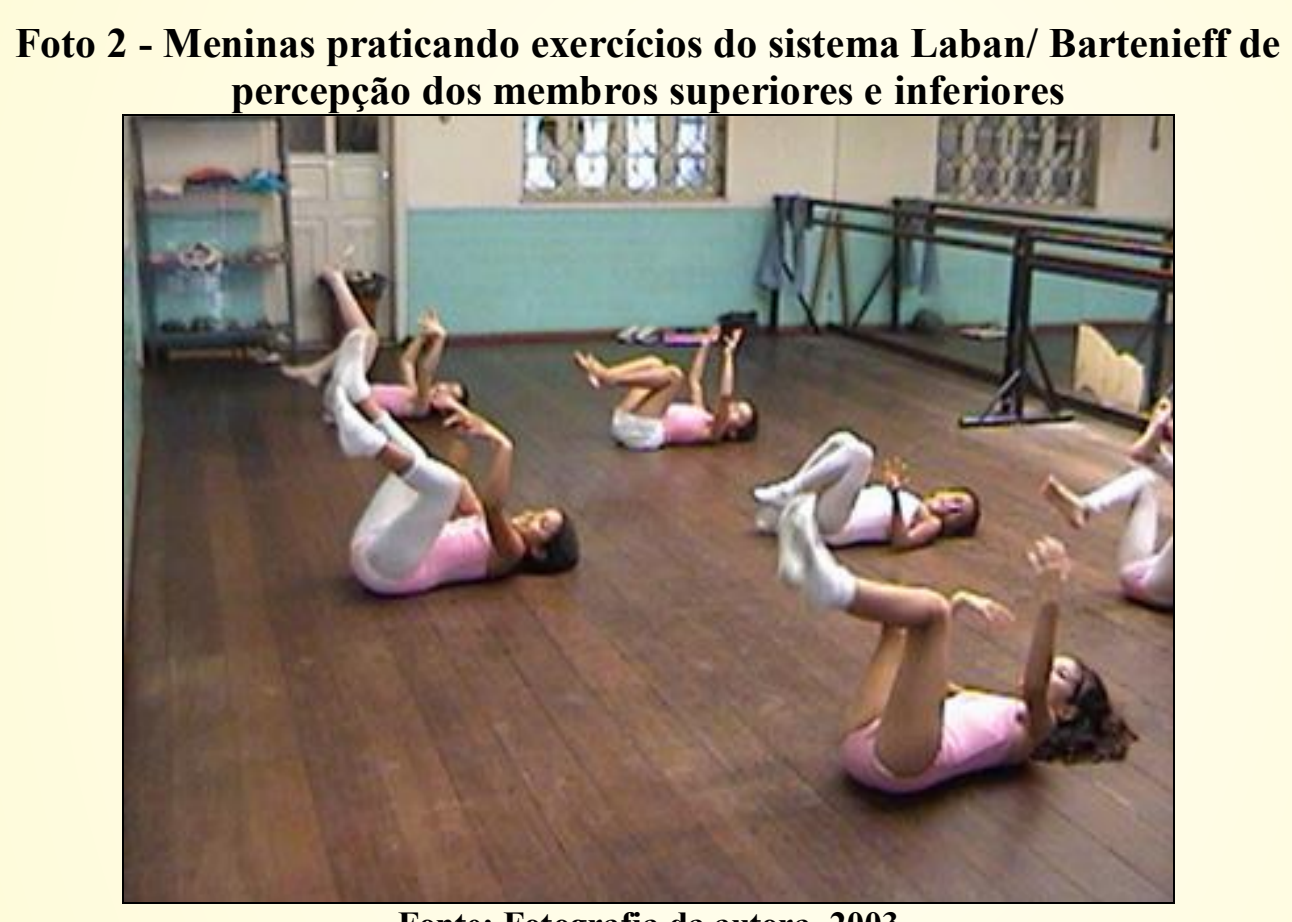

Fonte: Fotografia da autora, 2003

Nossas aulas eram finalizadas com as alunas em círculo e discutíamos sobre as facilidades e dificuldades encontradas nos exercícios, como também as descobertas que elas fizeram.

\subsection{Jogo brincando com as ações corporais}

\section{Objetivo:}

Desenvolver as aptidões perceptivas como meio de ajustamento psicomotor.

Foco:

Percepção do próprio corpo e do espaço/tempo/peso/fluência do movimento. 


\section{Descrição:}

Os exercícios eram feitos por meio das andadas no espaço, que consistia em as alunas andarem pelo espaço de sala de aula sem obstáculos. A cada exercício era escolhida uma ação corporal que poderia ser a de saltar, girar, cair, expandir, recolher, deslocar, inclinar, parar, torcer, transferir peso, gesticular/isolar.

\section{Comentário da vivência:}

Quando acabava o aquecimento com as vogais, pedia que as alunas começassem a andar pela sala de aula. Inicialmente, com uma dinâmica de andar normal, ou seja, como elas andavam na rua, no seu cotidiano. Essas aulas eram acompanhadas com as palmas que nas primeiras aulas eram feitas por mim e pelas duas alunas assistentes que me pediram para participar da experiência do estudo, pois trabalhavam com crianças. Nas primeiras aulas, observei que as alunas andavam muito em aglomerado e a qualquer momento se davam de encontro, o que fazia com que elas perdessem a concentração. A estrutura espacial se desenvolve na criança a partir do conhecimento adquirido em relação ao seu corpo e ao espaço que ocupa, resultando em uma melhor locomoção espacial, organização do espaço que ocupa e maior domínio de seu gesto.

Segundo Lê Boulch (1982), a tomada de percepção da situação de seu próprio corpo em um meio ambiente é lugar da orientação que pode ter em relação às pessoas e às coisas. Compreendendo a orientação feita pelo autor, passei a mostrar que o espaço não poderia ficar sem ninguém, não podia ficar vazio, assim que surgissem os buracos no espaço, deveriam estar atentas e se colocarem naquele lugar. Com esse procedimento, que começou a se repetir mais acirradamente nas aulas seguintes, consegui que as alunas percebessem mais o espaço em que estavam se deslocando e o que estava aos seus redores. Iniciaram a entender que existem mil maneiras de se jogar, o que me fez perceber que com esse entendimento criaram mais liberdade para se movimentarem "projetando formas para outras direções no espaço total" (RAMOS, 2007 p. 44).

As palmas para essa prática foram fundamentais. No início, a instrução era: três palmas e as alunas paravam de andar e só podiam sair do estado de estátua quando escutassem a palavra mexer. Em seguida, em cada parada demonstravam que podiam realizar uma das ações mencionadas acima. Esses exercícios foram fundamentais no aprendizado das crianças da oficina. Primeiro porque brincavam de fazer brinquedo com seu próprio corpo e depois porque na ação de torcer, por exemplo, começaram a experienciar o espaço e sua tridimensionalidade, pontuando 
com seus corpos, na tentativa de executar a ação de torcer os níveis do espaço, galgando os primeiros passos para o estudo do onde (espaço).

$\mathrm{Na}$ brincadeira com as ações, também foram introduzidos por meio das andadas (marcha) o salto e o giro. Entretanto, nessas duas ações, a dificuldade para a faixa etária era o giro. Sempre que tentava girar, a maioria das alunas perdia o equilíbrio. Todavia, para não desanimá-las, e castrar a espontaneidade de tentar o girar mesmo ainda com medo de cair, comecei a estimulá-las a utilizarem o cair como forma de voltar ao equilíbrio, possibilitando mais uma vez que vivenciassem o nível do espaço (alto e baixo) e eixo corporal e a confiança em si mesma.

A ação de saltar era a brincadeira mais natural para as alunas, haja vista suas faixas etárias. Portanto, nas andadas, quando as palmas ordenavam saltar, a sala explodia em milhões de forma de saltos diferentes. O subir e descer no espaço cada vez mais proporcionava a elas impulsos. Começavam a entender que seus corpos podiam ser o brinquedo e que isso as levava a grandes descobertas, inclusive, sobre o equilíbrio. Geralmente, no final das aulas, à volta a calmaria iniciava-se com a desaceleração dos passos até chegar ao deitar no chão e tomarem em seus corpos a forma da letra $X$, favorecendo que elas experimentassem toda a extensão de seus corpos para finalmente transformarem-se na letra $\mathrm{C}$.

\subsection{Jogo vamos desenhar}

\section{Objetivo:}

Aferir o conhecimento e a experiência motora que a criança tem da sua imagem corporal.

Foco:

Nível de noção e reconhecimento do corpo.

\section{Descrição:}

Recurso metodológico composto de pré-teste e teste baseado no desenho da figura humana.

\section{Comentário da vivência:}

Nos estudos do primeiro semestre de 2003, a brincadeira do Vamos desenhar foi de grande importância para dar início ao estudo da consciência corporal com as alunas da oficina do Curso Preparatório de Dança na ETDUFPA. Selecionei esse recurso metodológico para ser usado na investigação por se tratar de uma tarefa de fácil execução e pelo gosto que a criança demonstra na realização dos desenhos. Dessa forma, foi possível obter informação sobre a evolução da percepção corporal 
das crianças do estudo tornando-se importante recurso que me prestou auxílio na decisão e organização dos estudos sobre as atividades lúdicas que seriam processadas nos estudos do semestre.

Na primeira vez que foi utilizado esse recurso, estávamos em sala de aula de dança. Após o aquecimento corporal, apresentei às alunas o material para desenhar (composto de caixa de lápis de cor, papel branco, cartolina, borracha, tinta guache e alguns pincéis). No caso específico deste estudo, o primeiro desenho pedido foi o desenho de uma pessoa (desenho da figura humana). Para essa realização, utilizei a sala de dança para que as alunas pudessem ficar espalhadas, cada uma com seu material, evitando, ao máximo, que uma aluna tomasse como referência o desenho da outra.

Não estipulei tempo determinado e deixei que se colocassem como escolhessem, ou seja, deitada, sentada no chão ou em cadeira, ficou a critério da criança a escolha. No momento, interessava-me perceber como se comportavam nessas horas mais livres. Qualquer informação sobre aquelas crianças para mim eram importantes, pois precisava conhecê-las. Queria me inteirar de suas vontades, de seus hábitos, de suas preferências, ações/reações. Nas primeiras aulas, queria aproximálas e, no caso, o desenho foi fundamental como recurso de formação do grupo. Depois descobri que foi muito além, porque foi também o recurso que aproximou família, professor e escola.

Por meio dos primeiros desenhos pude entender como a criança da Oficina do Preparatório de Dança via a sua própria imagem corporal. Assim, pude detectar a carência no conhecimento corporal como o todo, pontuando inicialmente o segmento corporal e o eixo corporal. Aplicava o recurso do desenho no final de cada mês de trabalho e, dessa forma, fui aferindo, por meio dos desenhos, a evolução de cada criança em relação à consciência corporal. Foram experiências que me fizeram encaminhar para o segundo semestre uma prática que falasse mais de ludicidade, que oferecesse práticas mais espontâneas.

Esse recurso serviu para que pudesse entender como as crianças se relacionavam em suas casas, suas escolas, como se sentiam estudando dança, enfim, o que estavam achando (naquele tempo) do mundo que as cercava. Solicitei que desenhassem suas casas, suas famílias, escolas e amigos, informações dadas de maneira lúdica que serviram também como instrumento de entendimento sobre seus avanços corporais.

Esses desenhos, juntos com outros recursos metodológicos, como teste 
psicomotor (conhecer o padrão motor de cada criança) e formulário de entrevistas (anamnese), tinham como proposta levantar dados da vida das crianças, incluindo o modo que realizavam suas brincadeiras, ou seja, se na escola, se com amigos ou sozinhas, para quê. O objetivo era, com base nas informações, que eu pudesse organizar aula prazerosa, criativa e motivadora. Queria antes de tudo conquistá-las como professora, queria que frequentassem minhas aulas.

As sessões de desenho na pesquisa foram contempladas nas atividades extraclasses e serviram também como ponte de exercício de socialização e de afetividade. As alunas nesses encontros passaram a demonstrar mais harmonia em suas comunicações com os pares. Demonstraram ter muito prazer de estarem ali participando daquele momento e isso era percebido pelo carinho com que cuidavam do material que usavam para desenhar. Foi também o fio condutor para fazer com que os pais e responsáveis pelas alunas participassem do estudo e com isso conseguimos criar um clima entre alunas, professoras e pais, de muita afetividade, de amor, de harmonia. A escola pode, sim, ser inovadora de comportamentos e com isso preparar-se para os desafios do mundo globalizante. Apresento aqui alguns desenhos e suas evoluções. 
Foto 3 - Desenhos de uma aluna da Oficina Preparatória de Dança
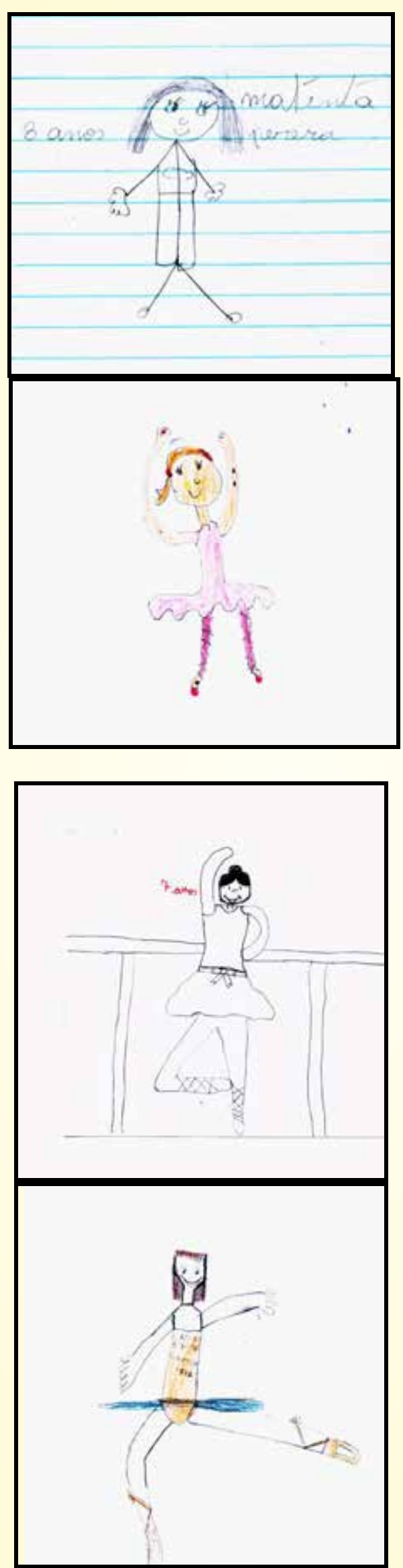

Fonte: Reprodução fotográfica da autora, 2003 


\subsection{Jogo conversando sobre dança}

\section{Objetivo:}

Aprimorar conhecimento sobre a dança.

\section{Foco:}

Dança clássica, dança moderna, dança folclórica.

\section{Descrição:}

Apresentação às alunas e a seus pais amostra de filmes de dança na ETDUFPA.

\section{Comentário da vivência:}

A ideia de apresentar filmes sobre dança às alunas e a seus pais partiu do momento em que percebi que conheciam pouco sobre a dança. Isso aconteceu no momento da primeira reunião que tive com os genitores das crianças para explicar como se desenvolveria as oficinas do Curso Preparatório de Dança. Observei que a maioria dos pais não aceitava outro tipo de dança que não fosse a dança clássica ${ }^{5}$. Todavia, mesmo escolhendo o balé clássico como favorito, descobri que muitos daqueles que estavam agarrados à ideia de que somente balé clássico é dança, nunca haviam assistido a um concerto de tal dança e imaginei que nem pudessem fazer ideia do que fosse uma dança moderna, muito menos quem fosse Pina Bausch. Claro que essas conclusões surgiram de nossas conversas e assim, no encontro seguinte, resolvi fazer uma surpresa: selecionei peças do repertório do balé clássico como Gisele e Quebra Nozes.

Comentamos sobre a dança clássica, como também contei as histórias dos repertórios mostrados. No encontro seguinte, dando continuidade à história da dança, apresentei filmes sobre dança moderna. Selecionei um grupo de bailarinas interpretando solos de Isadora Duncan.

Nas aulas seguintes, continuei trilhando a história da dança comentando sobre Martha Graham e apresentei filmes como Lamentation. Surpreendi-me quando uma das mães me perguntou: "professora porque esta bailarina se contorce tanto, parece sofrer muito?" Expliquei que a bailarina protestava com seu próprio corpo o seu tempo. Comentaram sobre o figurino usado por Graham e também comentei que aquele traje cênico usado na coreografia era para contrapor seus movimentos, usando as diagonais. Eram movimentos de súplica, de piedade, não de dor; mas o movimento parecia querer preencher algo que estava faltando.

No final da amostra, contei-lhes como surgiu a dança moderna e aproveitamos para refletir sobre o período clássico da dança, como também divagamos sobre o modernismo, sobre a liberdade de se expressar com o corpo,
Acredito que além da falta de conhecimento sobre a dança e virem de um ambiente em que por um tempo o balé clássico foi tido como dança de verdade. (Em Belém, as pessoas só iam assistir espetáculo de dança se fosse de balé clássico (influência da apresentação de Anna Pavlova, 1830, em Belém do Pará Teatro da Paz). Quando era de dança moderna, um pós-moderno, 0 teatro era vazio. As vezes, no espetáculo de dança moderna, ou de dança-teatro comparecia a classe artística. A maioria tinha fé no balé clássico, pois acreditava que modelasse suas filhas que os ajudasse a educá-las. Mais calmas, menos ansiosas, mais atenciosas, menos preguiçosas. As mães sonhavam com meninas que tivessem um comportamento feminino e muitas me disseram "tomara que esta menina melhore seu modo de andar e comece a reparar por onde anda, gostaria que fosse mais elegante". Todavia, como professora, naquele momento interessava-me exatamente pelo contrário. Precisava que as alunas esquecessem-se de como procediam em suas casas ou escola, pelo menos para aquele início, no processo. Queria que despertassem para seus corpos e fossem acompanhando suas próprias mudanças. Não queria que ficassem contidas, incomodadas por não poderem colocar para fora suas emoções. Não queria ter alunos crianças dançando sem vida sem saber o que estavam fazendo e principalmente, sem curtirem o que estavam contando com seus corpos (tanto em coreografia, como em sala de aula). Queria alunos expandidos que tirassem de seus interiores seus movimentos, que criassem seus espaços internos, individuais e fossem transformando em crianças longe de censuras e gozadoras de uma comunicação prazerosa e imediata (LOBATO, 2011, p.122). 
sobre a liberdade de criar. Aproveitei o tema e as convidei para assistirem ao ensaio de uma coreografia dos alunos do sexto ano de dança da ETDUFPA. Era um trabalho de dança folclórica sobre os movimentos do carimbo e do lundu.

Terminamos a aula no quintal da ETDUFPA, reunidas sob a velha, amiga e companheira mangueira. Continuamos a falar de dança, aproveitando do entusiasmo das crianças pelas danças que haviam conhecido. Ficaram impressionadas com um filme em que a bailarina vivia Isadora Duncan e mostrava com o seu corpo os movimentos que uma folha faz no espaço, quando vem caindo de sua árvore. Isadora fazia do seu corpo um corpo-folha.

A empolgação (tanto de minha parte como das delas) foi tanta que esquecemos que a aula tinha terminado. Mas com consentimento de seus responsáveis, prosseguimos a atividade com mais perguntas sobre a dança moderna. Percebi que histórias desse período da dança ganhou a simpatia das alunas que vibraram quando viram Isadora (neste mesmo dia no filme) virando fogo, ou dançando, feito labaredas. Falei da importância dessa bailarina para que existisse a dança moderna e contei-lhes um pouco sobre sua vida trágica. Pouco a pouco fomos trabalhando para que a ideia de só existir uma maneira de dançar não se processava mais. Pensei que informar sobre a dança e sua evolução para pais e alunas foi o instrumento que apresentei para ajudá-los a vencerem seus preconceitos sobre a questão do movimentar, sobre a questão dançar, mais principalmente, sobre a questão do brincar.

\subsection{Jogo do tempo}

\section{Objetivo:}

Estimular a percepção da duração e variação da velocidade do tempo.

\section{Foco:}

Dinâmica do tempo (acelerado, desacelerado, repentino), ritmo.

\section{Descrição:}

O exercício com o fator tempo variava a velocidade do movimento que ia se tornando acelerado ou desacelerado.

\section{Comentário da vivência:}

Com uma aula de dança, iniciei o teste psicomotor com as crianças da oficina. Entretanto, uma dança sem estilo, sem padrão, criada por cada criança. Como professora, entrei na dança com elas e movimentava-me de acordo com os 
sentimentos que a música ia provocando em meu corpo. As alunas ficaram mais seguras nessa brincadeira com minha presença, embora a reação do início tenha sido a de rirem do meu jeito de dançar ${ }^{6}$, mas depois cada uma começou a dançar livremente e entraram na mesma energia.

A maioria fazia movimentos que pareciam do balé clássico. Outras procuravam desajeitadamente um movimento e algumas tentavam imitar a dança que eu executava freneticamente. No final da música, que era de percussão, estávamos devidamente aquecidas para darmos prosseguimento aos exercícios de acelerar e desacelerar o tempo do movimento, começando com passos normais, acelerando pouco a pouco até chegar à corrida.

Em seguida a esse exercício bastante aeróbico, que deixava as alunas eufóricas e alegres, trabalhei a lateralidade, ou seja, um lado e o outro do corpo em movimento $^{7}$. Por meio das palmas, controlava o tempo, dizia se o tempo era rápido ou lento, e também ditava o ritmo e o ordenava livre, contido ou sinuoso.

A esse jogo, no segundo semestre, acrescentei o jogo um ponto perto, um ponto longe que auxiliava as crianças exercitarem suas cinesferas ${ }^{8}$, ou seja, expandindo o corpo como se buscasse o ponto mais longe no espaço e ao mesmo tempo encolhendo seu corpo, experimentando o ponto mais próximo do seu corpo. Essa imaginação era aguçada nas alunas com as palavras dentro e fora. No movimentar da cinesfera, quando um grupo estava perto do ponto central, o outro, afastava-se. Nesse vai e vem, pedia estátua a elas que imediatamente correspondiam à brincadeira.

Começaram a perceber que havia uma variação no tempo do movimento que estavam praticando. E que, dependendo do exercício, o movimento se tornava gradualmente mais rápido ou mais devagar, ou seja, acelerado quando ficava cada vez mais rápido e desacelerado quando ficava cada vez mais lento.

Nas práticas da segunda oficina, para a brincadeira de explorar o tempo do movimento, acrescentei à brincadeira usar palavras. O jogo consistia em dizê-las em diferentes velocidades. Lembro que a palavra socorro foi dita em diferentes velocidades e com isso variava a intenção de pronunciá-la.

Como jogar com a cinesfera me pareceu ter sido para elas bem divertido, passei a perguntar quem lembra como fazia com seu corpo quando era bebê, ou quem já prestou atenção aos movimentos dos bebês, que podia ser um irmãozinho, ou vizinho? Logo uma aluna me disse: professora, meu irmãozinho é bem pequenininho e ele faz assim, olhe! Então, ela deitou-se ao chão encolhendo
${ }^{6}$ Procurava

movimentar-me quebrando bem o corpo, meio sacudindo os seguimentos corporais, mostran $\neg$ dome desfocada enquanto uso do espaço, mas muitas vezes contida, pausada.

Descobrindo a lateralidade não no sentido de direito e esquerdo do corpo, mas no sentido de troca de peso, de um lado e do outro, como um pêndulo, no sentido do movimento.

Segundo Rangel (2005), cinesfera é a esfera dentro da qual acontece o movimento. Também é denominada Kinesfera (p.32). Cada agente tem sua própria cinesfera a qual se relaciona somente a ele. Essa esfera do espaço cerca o corpo, esteja ele em movimento ou em mobilidade. É delimitada pelo alcance dos mem $\neg$ bros e de outras partes do corpo do agente quando se esticam para longe do centro do corpo, em qualquer direção, a partir de um ponto de apoio (p.33). 
suas pernas, esticando e se desdobrando, imitando como os bebês se movimentam. Com essas imitações comecei a estimular a percepção de quando o bebê se movimenta. Essa brincadeira também servia para que com essa demonstração feita uma a uma (o bebê que ela tinha observado), as alunas que assistiam repetissem os mesmos movimentos.

Acrescentado ao fator tempo a afinidade espacial, pedi que imitassem um bebê tentando andar e elas me mostraram o bebê que ia quase correndo para frente ou tentando andar para trás, mas que caia no chão. Esse movimento que passamos a chamá-lo bebê serviu para que compreendessem que quando crescem o movimento do bebê, (abriam e desdobravam o corpo) está tendo seu volume aumentado e que quando encolhido (fechando e dobrando), o volume é diminuído (FERNANDES, 2002).

A partir desses exercícios, passei a insistir com os exercícios que as levassem a ter contato como o chão. Solicitei que as alunas deixassem seus corpos ainda no chão e que fossem se transformando na letra $\mathrm{X}$ e com isso, como diz Fernandes (2002, p. 44), começaram a experienciar a respiração celular que consiste exatamente no enchimento e esvaziamento corporais trazendo vida a todo corpo. $\mathrm{O}$ corpo vibra com a reverberação da respiração. Isso as fez sentir mais vigorosas, mais corajosas.

Nas práticas sobre o tempo, considerei os exercícios imitando os bebês e as andadas como os mais flexíveis e criativos tanto para o meu aprendizado como professora como para o aprendizado de meus alunos no que diz respeito à percepção temporal. As variações advindas desses laboratórios de andadas e rolamentos eram muitas e a essas atrelei as brincadeiras de andar comandada pelo ombro.

Nesse exercício, referi-me à questão da lateralidade (que em casa aprenderam que seria usar a mão direita ou a esquerda) e fazia com elas, comandadas por seus ombros, andassem para um lado e para o outro percebendo o peso de seus corpos. O mesmo acontecendo quando caminhavam para frente ou para trás no espaço, experienciando a ação de transferir o peso do corpo de um lado para o outro, descobrindo seus equilíbrios e desequilíbrios.

Quando discutíamos no final das aulas, fazia questão de descobrir com elas, além de suas dificuldades de compreensão de praticar os exercícios, denominações para alguns desses exercícios, como no caso do imitando os movimentos dos bebês, ou do imitando o $\mathrm{X}$ que virou a estrela do mar. Compreendi que era muito importante fazer o exercício com a criança, mas associá-lo sempre a uma imagem. 
Assim como também entendi que viravam exercícios/repertório se precisasse usá-los como parte de coreografia (as andadas, a estátua, os rolamentos, são exemplos desses).

Com a imagem da estrela do mar na memória, as alunas começaram a perceber que o abdômen irradiava força para o corpo todo, ou seja, descobriram com essa brincadeira que a respiração irradiava as seis pontas de seus corpos, ajudando-as a perceber que essas seis pontas da estrela do mar são: duas mãos, dois pés, cabeça e cauda (FERNANDES, 2002 p. 45). Descobriram que quando faziam seus corpos de bolinha aproximavam a cabeça de seus cóccix e com isso ganhavam várias formas de velocidade ao se locomoverem, principalmente no nível baixo do espaço.

Quando a aula sobre o tempo começava com uma dança/improvisada, na maioria das vezes, isso as estimulava para que, no final, também terminassem dançando. Essa dança sempre era de improviso, ou seja, sem combinar, algo inesperado e inacabado, vivendo o aqui e o agora da experiência.

Geralmente iniciava com a dança do ombro. Tal dança fazia todo mundo pensar e deslocá-lo. Isso forçava sempre que andassem para frente ou para trás. A mesma coisa acontecia com a dança do pescoço. Era uma forma de aquecimento que usava no início das aulas para que as alunas fossem pensando em cada parte de seus corpos. Fazíamos muito a dança de fazer rotação com os punhos ou com os tornozelos, ou aquelas com uma perna só, alternando direita e esquerda. Depois passaram a praticar o jogo em pares.

\subsection{Jogo vamos nos deslocar}

\section{Objetivo:}

Propiciar que as alunas conheçam mais variedades de deslocamento no espaço, no tempo.

\section{Foco:}

O corpo como o todo (partes = cabeça, tronco, membros e superfície), ação corporal, ritmo, coordenação global, dinâmica geral.

\section{Descrição:}

Aquecimento (brincando de respirar com as vogais), seguido dos rolamentos até chegar à posição de pé. Andando pelo espaço, com um peso leve, ou firme, acelerando e desacelerando o tempo do movimento que dependendo da ação dos esforços, poderia ser quanto ao espaço direto, ou indireto, com uma fluência livre ou 
controlada.

\section{Comentário da vivência:}

Denominei essas aulas deslocamento, pois, além de termos que nos deslocar espacialmente (mudamos de sala de aula para a caixa preta, ou Teatro Claudio Barradas), precisamos nos deslocar no tempo (passamos a ter aulas também no sábado).

Solicitei mais uma vez a participação dos pais, pois como nossas aulas eram somente duas vezes na semana, senti necessidade de mais tempo para a prática dos exercícios com as crianças. Essas aulas começavam às $14 \mathrm{~h}$ e terminavam às $18 \mathrm{~h}$, sempre aos sábados.

Nas práticas das aulas de sábado, utilizei bastante o chão como elemento de um alto grau de importância para a percepção dos eixos corporais. Corpo no chão e trabalhando a respiração com sonorização foram exercícios fundamentais para que as crianças, por meio das vogais, pudessem brincar na tridimensionalidade do espaço até chegar no nível alto para iniciarem a realizar a sequência (I, E, A, O, U), levando cada respiração e o tato para os órgãos indicados.

Muitas foram as brincadeiras surgidas com as ações do esforço. As alunas se faziam de pássaros e passeavam pela sala combinado seu corpo com a palavra flutuante, bem como brincando de imitar o pulo do sapo que era feito de uma maneira tão enérgica que muitas vezes fui capaz de perceber como pareciam presas no chão e de repente leves no espaço. O interessante do exercício era que cada uma das alunas era o sapo que tinha escolhido ser. Para o deslize do corpo, as alunas experimentaram a cobra e para se chacoalhar as alunas imaginaram limpar uma casa usando o espanador como objeto imaginário para tal limpeza. Falavam que era assim que suas mães faziam.

Assim, a cada sábado, colocava uma ação nova de esforço como pressionar e socar e, passo a passo, fui conseguindo que as alunas misturassem suas ações de esforço e começassem a aproveitar as sequências que uniam à coreografia. Primeiro pedi que misturassem suas ações em pares, depois em trio e assim fui criando comigo as sequências coreográficas que denominei As junianas e suas brincadeiras.

O jogo do deslocamento, além de ter se colocado como um elemento da composição coreográfica fundamental para a montagem coreográfica, também trabalhou o ritmo, a coordenação global, a dinâmica geral, bem como ajudou para o entendimento da estruturação da coreografia. Com a prática do exercício passamos a 
alertar as alunas sobre o que era um espaço vazio, ou do cuidado que deveriam ter para não atropelarem a vez da colega, na dança, mas conseguissem se comunicar harmonicamente no espaço com as brincadeiras.

Esse jogo nos deslocou também em direção à sala de objetos cênicos, que chamamos a caixa preta, e possibilitou que as alunas pudessem conhecer nossa sala de brinquedos que denominei a sala das ilusões. Ali estavam guardados cenários, objetos cênicos, bem como vestuário que sempre eram reutilizados em outras peças de teatro ou de dança. Eu e minhas alunas, num dos sábados, passamos a escolher o que dali poderia fazer parte do cenário da coreografia As junianas e suas brincadeiras. Conseguimos para compor nosso cenário: duas cadeiras, tecidos e restos de fitas coloridas. Também as meninas escolheram colher de pau, panelas e algumas bonecas de pano que por ali se encontravam.

Esses objetos conseguidos na sala preta, ou das ilusões foram utilizados em nossas aulas como obstáculos para as andadas no espaço. Afinal, se eram objetos que iriam participar da coreografia, as alunas precisavam conhecê-los melhor e, dessa forma, descobrir por elas mesmas como utilizá-los, mas principalmente como superálos como obstáculo.

As cadeiras ora ficavam deitadas no espaço, ora eram colocadas de outra forma. As alunas, às vezes, passavam por cima das cadeiras, outras vezes sentavam nelas, giravam em torno. Deslocamo-nos também no sentido musical, pois como apresentaríamos nossa coreografia, num projeto denominado Feira Junina da ETDUFPA, passamos a ouvir músicas da época e, assim, também escolhemos juntas a música que faria parte da coreografia.

Como o tempo de sábado era bastante longo para nossos encontros (passávamos a tarde toda juntas), terminávamos sempre as aulas em círculo com as alunas cantando trechos de músicas que lhes trouxessem uma lembrança. O jogo de cantar uma música que lhe traga uma recordação iniciava no momento em que eu tocava em uma aluna que deveria começar a jogar. Também todas deveriam manter os olhos fechados e assim iam cantando a música que era escolhida por elas, mediante um acontecimento que poderia ser: lembranças de suas casas, situações vividas nas escolas, seja o que fosse, mas que tivesse um significado, que representasse algo para elas, algo significante para suas vidas, algo que tocassem seus âmagos. Percebi que iniciava a ler aqueles corpos. 


\subsection{Jogo identificação de objetos}

\section{Objetivo:}

Estimular a sensibilidade do tato, descobrindo com os olhos fechados qual é o objeto apresentado.

\section{Foco:}

Forma, textura e cor do objeto.

\section{Descrição:}

Alunas ordenam-se em pé e em círculo. Uma delas é chamada para o centro, onde fica com as mãos para trás, de olhos vendados. A coordenadora põe um objeto real na mão da jogadora. Usando apenas o sentido do tato, a jogadora deve identificar o objeto. Quando a jogadora identificar o objeto, pode olhar para ele. Então outra jogadora é chamada para o centro e recebe um novo objeto para identificar.

\section{Comentário da vivência:}

O jogo, além de ter divertido imensamente a nós todas, deu oportunidade para que as alunas vivenciassem mais os brinquedos que fariam parte da coreografia. Dessa vez, fui eu quem trouxe para elas os brinquedos que pensava em oferecer para imaginarem comigo a coreografia. No dia da aula, deixei para entrar em sala quando elas e minhas alunas/assistentes já estivessem presentes. Quando abri a porta e dei um passo para dentro da sala de aula, todas as alunas grandes e pequenas correram em minha direção para saber que saco era aquele (lembrava o de papai Noel) que eu estava trazendo.

Era uma surpresa, mas também uma brincadeira. No saco, sem que elas soubessem, trazia mastros com fita (que lembravam os mastros carregados pelos brincantes do boi-bumbá), duas marionetes que eram do boi-bumbá, um saco com folhas secas de uma árvore da rua, cestos de palha enfeitados com fitas, asas de anjos (aquelas que usam no Círio de Nazaré, no carro dos milagres), rosas de várias cores de papel crepom.

Dentro do saco havia onze objetos relacionados com a coreografia As junianas e suas brincadeiras, mas nenhuma delas sabia que objetos eram aqueles. Quando dava o objeto na mão da aluna que vinha até o centro eu perguntava: para que serve este objeto? Qual é a sua cor? Principalmente quando percebia que a aluna estava perdida ao descrever o objeto, tateando. Spolin (2010) diz que embora seus jogos estejam dispostos em seu fichário em sequência, podem ser usados de forma flexível quando se trata de necessidades instrucionais específicas. No caso, utilizei o 
jogo em questão porque acreditei que iria ajudar as crianças entenderem o que era a coreografia (o que queríamos contar), o que era a quadrilha (que tipo de dança), sua origem e como era organizada e executada em Belém do Pará.

Nesse dia, as alunas tiveram outra surpresa. Duas mães se organizaram (sem que as filhas soubessem) e providenciaram os vestidos para a quadrilha. Dessa maneira, fiquei sabendo que todas já haviam participado de festa de São João e de quadrilha. Terminamos a aula numa dança de São João, com as meninas vestidas com vestidos caipiras e experimentando os objetos selecionados.

\section{Foto 4 - Meninas escolhendo objetos cênicos para a coreografia As Junianas e suas brincadeiras}

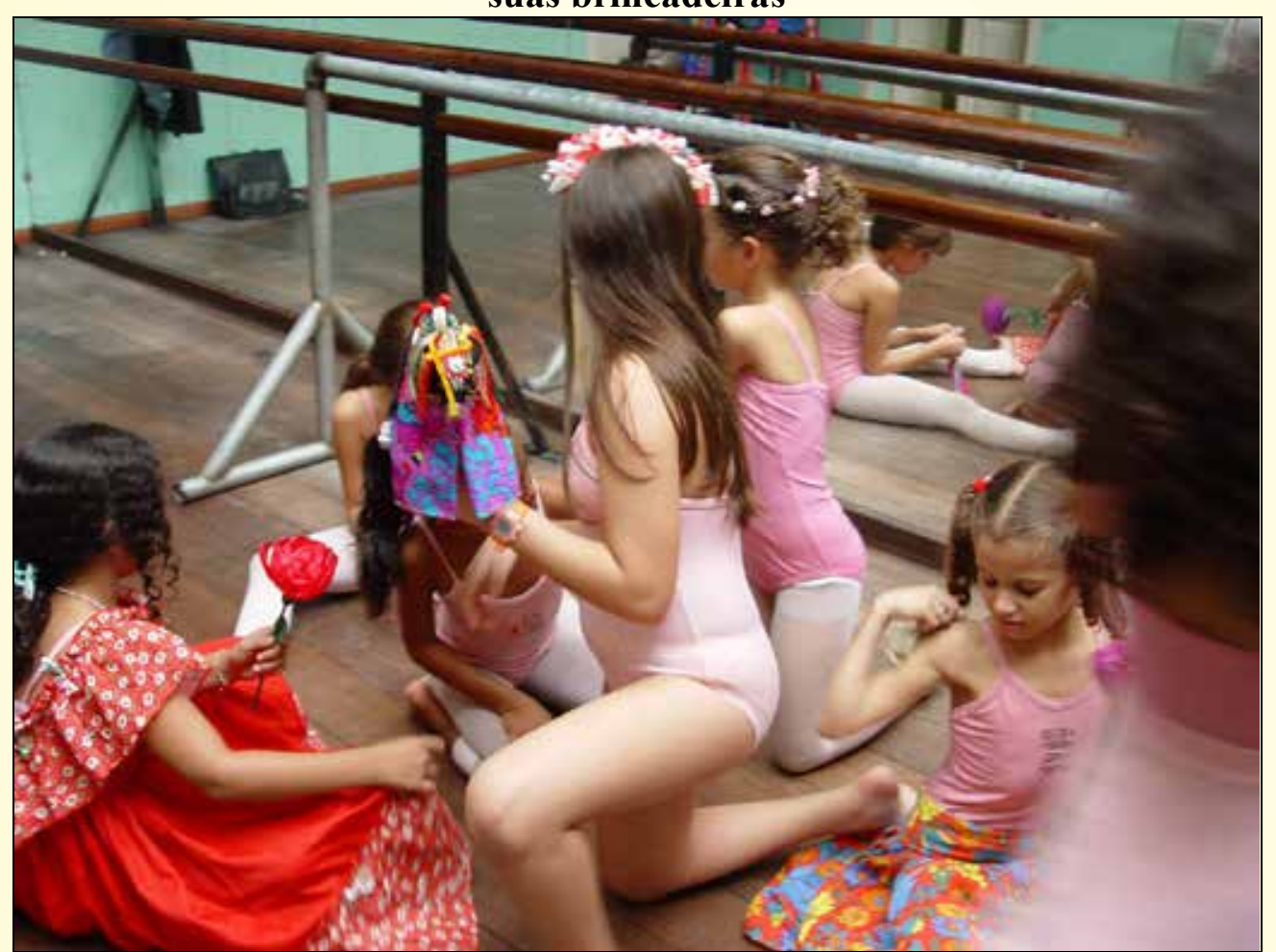

Fonte : Fotografia da autora, 2003.

\subsection{Jogo das historinhas sem palavras}

\section{Objetivo:}

Estimular o uso do gestual, prescindindo da palavra para contar uma história.

Foco:

Forma de comunicação.

\section{Descrição:}

Alunas em círculo. Uma aluna vai ao centro e forma um gestual e fica parada (estátua) para que as outras que estão no círculo possam imaginar o que aquela aluna está dizendo com aquela pose. De interpretação à interpretação, as alunas vão se 
unindo e, finalmente, quando todas estão em cena, termina o jogo para começar novamente acrescentando-se novas propostas.

\section{Comentário da vivência:}

O jogo das historinhas sem palavras era um jogo que acontecia para finalizar a aula. $\mathrm{O}$ exercício consistia em um círculo em que uma aluna voluntária ia até ao centro e mostrava com movimentos como estava sentindo seu corpo naquele momento que acabava de ser despertado pelos exercícios praticados. Queria que as alunas pensassem seus corpos integralmente, como um todo, mas também como partes. Nesse jogo, utilizava também objetos cênicos. Às vezes, pendurava um tecido no teto e pedia a elas que fizessem uma historinha sem palavras, mas incluindo o objeto cênico.

Em algumas vezes esses exercícios eram feitos com a aluna que ia até o centro da cena e contava sem falar como estava se sentindo naquele momento. As outras que estavam no círculo observavam o que a do centro fazia inclusive aqueles movimentos que fazemos, mas não temos consciência de que fazemos. Quem olha vê, quem faz não percebe. Com a prática dessa brincadeira, essa percepção foi se tornando mais aguçada e isso nos ajudou muito na montagem da peça do final do ano.

Interessava-me que observassem o que a aluna no centro estava dizendo com seu corpo e que depois de compreendido repetissem juntas com o criador do movimento inicial. Esse exercício permitia que elas tomassem decisão e, por isso, tomava cuidado no início para que elas pensassem no espaço e pudessem diversificar os níveis do espaço quando contavam a história.

No primeiro semestre, faziam pouca variação no espaço, ou faziam quase tudo no nível alto, ou uma ou outra aluna ariscava-se a experimentar seu corpo no nível médio do espaço. No segundo semestre, utilizei o jogo em quase todas as aulas. Para que se movimentassem, precisavam aumentar a suas capacidades de percepção no sentido de descobrirem seu espaço pessoal e, consequentemente, descobrissem o espaço individual dos outros. Tinha necessidade que elas se conectassem.

Foi um jogo importante no desenvolvimento da concentração das alunas, pois praticando-o terminavam pensando em seu corpo enquanto que os outros que olhavam se deliciavam com a expressividade do que estava no centro do círculo, tendo que em seguida repetir o movimento imitando inclusive a expressividade do modelo. Era um jogo muito divertido e as alunas adoravam fazê-lo. Todas queriam experimentar, dizer alguma coisa com seu corpo. 


\section{Foto 5 - Aluna contando uma História sem palávras com auxílio doobjeto cênico}

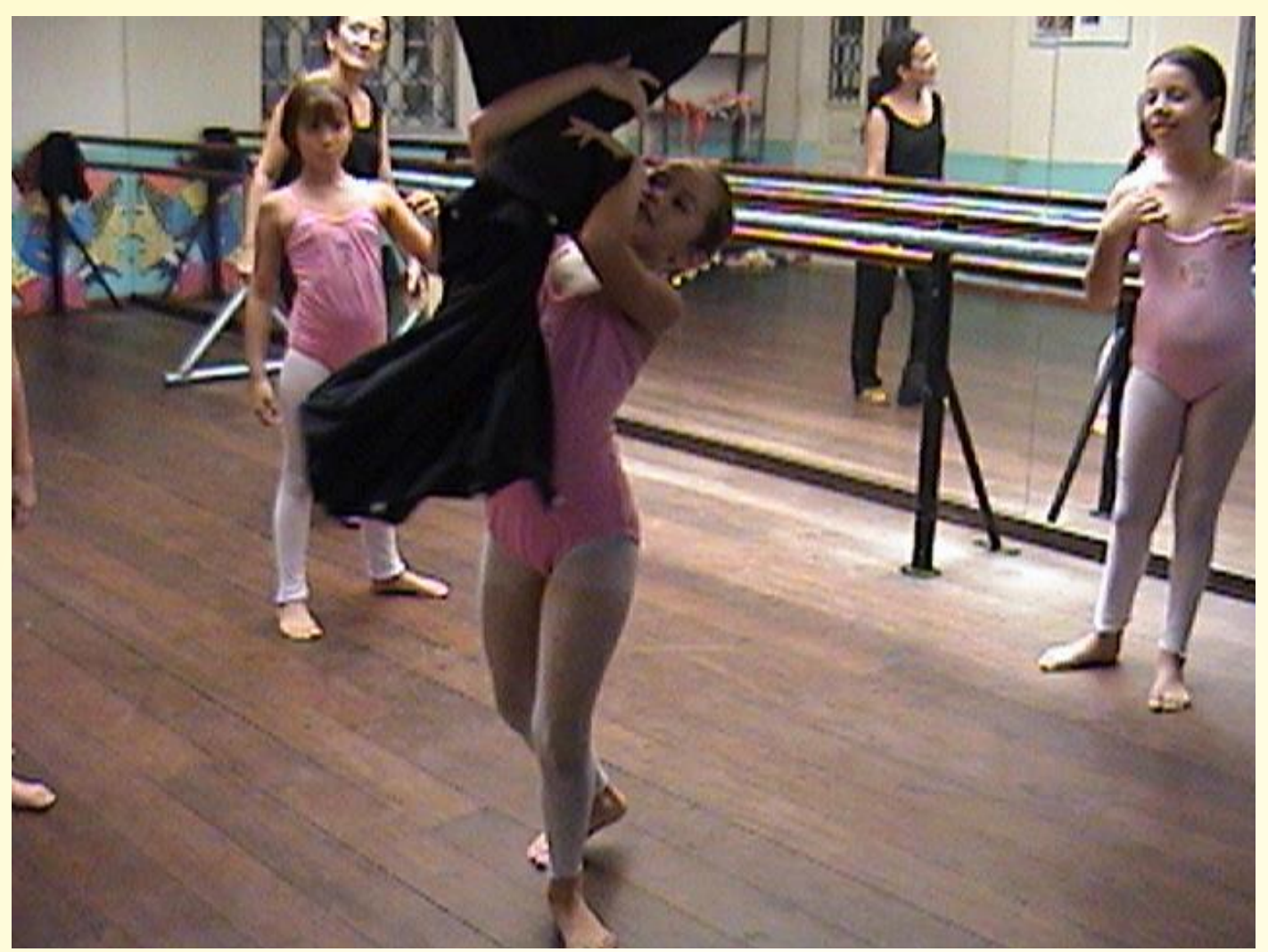

Fonte : Fotografia da autora, 2003.

\subsection{Jogo do olho no corpo}

\section{Objetivo:}

Propiciar às alunas nova forma de mover seus corpos no espaço e tempo.

Foco:

Segmento corporal, eixo corporal, equilíbrio.

\section{Descrição:}

O grupo todo coloca um olho no lugar em que o coordenador mandar colocar, ou seja, mão, pés, pernas, braços, ombro, sola do pé, costas, abdômen, cabeça. O aluno começa a olhar o espaço com esse olho e pode ser colocado em qualquer parte do seu corpo.

\section{Comentário da vivência:}

No exercício o aquecimento começava pelo chão, seguido das andadas até chegar num ponto em que todo o grupo parava. Cada um no lugar que escolhia no espaço. O exercício iniciava-se a partir da voz de comando a mover-se pela sala sendo levado por um olho que queria ver tudo o que tinha na sala de aula. Olho esse 
que impulsionava o aluno a experimentar, a mover seu corpo em todos os níveis do espaço até que ouvissem a palavra troca. Esse exercício possibilitou melhorar o equilíbrio das alunas, pois dependendo de onde era colocado o olho, exigia que elas mantivessem mais concentração para a realização da tarefa.

Ao longo dessa prática, passei a usar a música e deixei que as alunas livremente colocassem o olho no lugar que elas escolhessem. Dessa forma, passei a integrar o grupo. A maior dificuldade acontecia quando colocava o olho na pélvis, como também centralizado na nuca. As próprias alunas decidiram ver com o olho o corpo do outro e, dessa forma, terminaram trabalhando individualmente, em dupla e coletivamente.

O exercício permitiu que as alunas se aproximassem mais umas das outras e também auxiliou as mais tímidas a entrarem no jogo, bem como visualizassem de forma variada o espaço. Dessa forma, pude dizer a elas que o corpo quando adquire uma posição está olhando para todos os lados do espaço e, quando dançamos, não devemos esquecer que o corpo tem olhos para todas as direções do espaço. Por isso, deve ser expressivo em todas as direções. Todavia, com tensões e intenções diferentes.

\subsection{Jogo o animal que sou}

\section{Objetivo:}

Propiciar ao aluno observar movimento, ritmo e características físicas reais dos animais.

\section{Foco:}

Ritmo corporal, expressão facial e som vocal de seu animal.

\section{Descrição:}

O grupo todo, se possível, deve ser levado ao zoológico ou fazenda para observar o movimento, ritmo e características físicas reais dos animais - o osso e as estruturas raciais são tão importantes como observação quanto ao mais óbvio movimento. Dessa forma, os alunos terão uma impressão real para recapturar e não simplesmente observar uma figura de um livro. A generalização deve ser evitada para que o exercício tenha valor. Separadamente cada aluna decide qual animal vai retratar. As alunas não precisam discutir sua escolha entre si. Cada aluna deve assumir exatamente as qualidades físicas de seu animal e mover-se peço espaço da sala de aula. As alunas devem ser relaxadas para poderem observar os animais com 
tranquilidade.

Quando as alunas tiverem se entregado totalmente para as qualidades do animal e tiverem captado novos ritmos corporais, peça que façam os sons desses animais. Continuar a instrução até que tenham desaparecido as resistências, e sons e movimentos corporais estejam integrados.

\section{Comentário da vivência:}

O jogo foi bastante curtido pelas alunas. Como no primeiro semestre de 2003, no segundo, continuamos com os encontros extraclasse (professor, pais e alunos). Decidimos nos deslocar para fazermos o jogo. Várias foram as tardes em que visitamos o Parque Zoobotânico, do Museu Paraense Emílio Goeldi, com as crianças da oficina.

\section{Foto 6 - Visita ao Parque Zoobotânico}

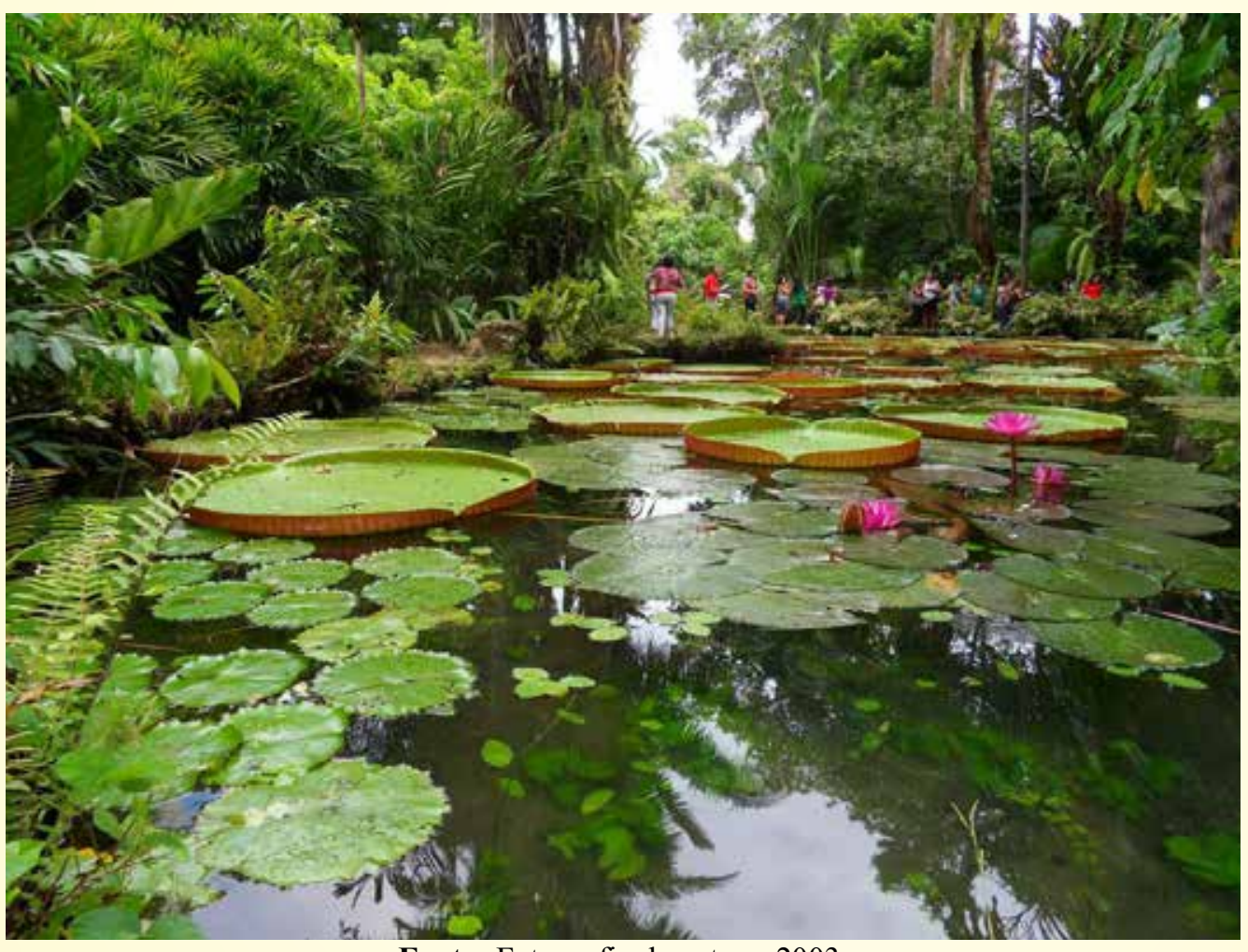

Fonte: Fotografia da autora, 2003.

Geralmente, quando ia me deslocar para fora da escola, pedia que pelo menos duas mães nos acompanhassem. Assim, podíamos dividir com elas o cuidado com o deslocamento das crianças, embora o local visitado ficasse a poucos passos da escola de dança. Praticamente só precisávamos atravessar a rua para estarmos no parque. Entretanto, dias antes da visita, precisava oficializar junto à escola e junto ao parque a realização do laboratório que iniciava por uma Solicitação de Visitação. Nessa 
solicitação, deveriam constar o nome da escola visitante, nomes dos alunos e dos professores e responsáveis envolvidos. Deveriam ser especificado o horário, visto que as visitações eram feitas de acordo com o regulamentado.

Nos dias de sair da escola organizava com as mães o que as crianças deveriam trazer de casa para que pudéssemos permanecer no local (no Museu) durante um horário prolongado na tarde do dia escolhido. Preparadas, saíamos com as crianças rumo ao parque. Solicitava que as mães as ajudassem a se colocar em fila indiana. Dessa forma, os adultos ali presentes (eu, uma de minhas alunas assistentes e duas mães) portávamos as alunas para aventurarem-se naquela reserva que, além de conter um acervo indígena valiosíssimo, oferecia a apreciação de animais.

Eu tomava todo cuidado para que nada fora do esquema traçado viesse a acontecer com as crianças na trajetória. Organizei e entreguei às duas mães, que se ofereceram para colaborar nesta investigação, uma ficha na qual constaria como as alunas deveriam fazer suas averiguações a partir do animal escolhido. As alunas ficavam horas observando os animais. A maioria escolheu os pássaros, levinhos e flutuantes com seus andares quicados, saltitantes e rápidos [serelepes]. Outras observaram a onça, principalmente a pantera negra, que fazia com que gritassem quando esta chegava perto da jaula e rosnava mais ferozmente que um gato, fazendo com que as crianças e o público recuassem. $\mathrm{O}$ animal parecia enfurecido e andava de um lado para outro sem parar. Às vezes, parava, mas logo em seguida levantava e demonstrava-se irritado com as visitas. Uma aluna que fez a mesma observação, no caso da onça, disse-nos: "sabe o que é tia? É que a onça não gosta de todo mundo olhando para ela. Acho que ela gostaria de ficar na selva e não presa naquela gaiola”.

Ficaram apaixonadas pelos macacos, mas se divertiram muito com as lontras (que pareciam muito alegres mergulhando de quando em quando na água, sem falar nas araras, no tatu, no tamanduá (que levava horas para se locomover de um lugar para outro com suas pernas tortas e unhas imensas).

$\mathrm{Na}$ aula seguinte, pedi que mostrassem em círculo, em sala de aula, que animal havia escolhido. Como tinham incorporado em seus corpos as características e o som que o animal fazia, solicitei que pensassem como esses movimentos que elas haviam selecionado poderiam virar uma dança. Falando assim consegui que uma aluna experimentasse o animal da outra e fosse criando movimentos em que, ao longo do treinamento, viraram sequências para seus aquecimentos,antes que começassem os jogos teatrais.

As observações feitas no zoológico com os animais serviram para que 
tomassem consciências das diferenças. Começaram com as dos animais e terminaram descobrindo suas próprias. Isso surgia quando trabalhavam em pares. Começaram a perceber que também fisicamente eram diferentes, inclusive o modo de andar. Umas andavam mais sacudindo os braços para frente e para trás, outras moviam lateralmente. Percebi também que nas aulas de dança, quando praticadas com a música, cada uma achava seu ritmo e modo se movimentar. Iniciamos, dessa maneira, a discussão sobre individualidade e diferenças.

Foto 7 - Meninas praticando $O$ jogo do animal que sou em sala de aula da ETDUFPA

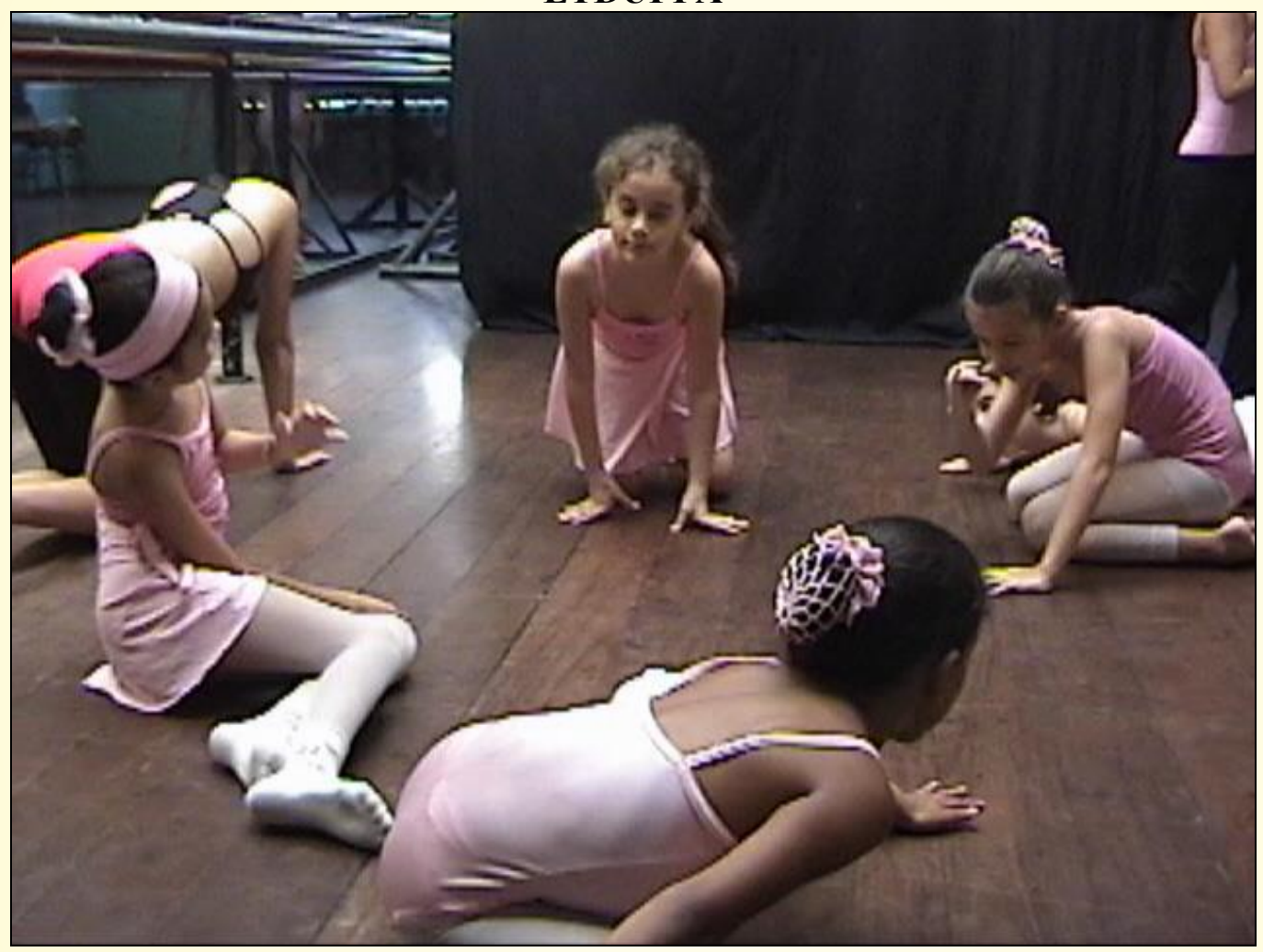

Fonte: Fotografia da autora, 2003. 


\section{CONSIDERAÇÕES FINAIS (IN)CONCLUSÕES}

Terminar é o mais difícil de tudo, mas, mesmo assim, e a desistência que proporciona a única experiência verdadeira de liberdade. Então o fim, torna-se mais uma vez o começo e a vida tem mais uma palavra.

Peter Brook

Com o Processo Jogo/Dança foi iniciado com as alunas um processo para a preparação do imprevisto, pois nas cenas da dança em questão tiveram que resolver muitas situações que surgiram na hora da apresentação que não haviam combinado, como foi o caso de espalhar folhas pelo chão da cena, improvisando o caminho que atravessariam o espaço e assim surgiu: o serpentiado em linha reta, em giros, quebrado, ou feito em zig-zag. Sabe-se que foi possível a improvisação porque aquelas alunas estavam com seus corpos livres, respirando, fluindo, em que a atenção está presente, pois um corpo tenso não escuta e não olha. Serviram, também, para que eu compreendesse que um professor não se faz apenas de conhecimento de conteúdo. Há necessidade principalmente de amor e é preciso que sejamos sensíveis na forma de transmiti-lo, para que, como diz Melo (1997, p. 64), "o processo educacional seja vivido com base de competência, responsabilidade, respeito e satisfação".

A partir deste estudo com crianças, passei a experimentar o Processo Jogo/Dança com alunos adolescentes e adultos e a defender que o fenômeno da ludicidade foca a experiência como uma experiência interna do sujeito que a vivencia. 


\section{REFERÊNCIAS}

FERNANDES, Ciane. O corpo em movimento: o sistema Laban/Bartenieff, na formação e pesquisa em artes cênicas. São Paulo. Annablumme, 2002.

KOUDELA, Dormien Ingrid. Jogos teatrais. São Paulo. Perspectiva, 1998.

LÊ BOULCH, Jean. A educação pelo movimento: a psicocinética na idade escolar. Porto Alegre. Artes Médica, 1982.

LUCKESI, Cipriano Carlos. Ludicidade e atividades lúdicas: uma abordagem a partir da experiência interna. Programa d Pós-Graduação, em Educação, 2000.

LOBATO, Lúcia Fernandes. Potenciais de dança para um corpo-bio-grafia. Salvador: PPGAC, 2011.

LOUREIRO, João de Jesus Paes. Desfolhamento Cultural: o trágico desencantado. Revista Ensaio Geral, v. 3, p. 65-77, 2011.

MARQUES, Isabel A. Os jogos do corpo: do lúdico ao cênico.: In: BENVENUTTI, Alice. O lúdico na prática pedagógica. Curitiba: IPEX, 2009.

MARQUES, Mariana Garcia. Consciência corporal: possibilidades pedagógicas n aprendizado da dança. 1999, 72 f. Monografia (Especialização) - Faculdade de Arte do Paraná, 1999.

MARQUES, Mariana Garcia. O desabrochar do corpo: a avaliação diagnóstica no processo de ensino-aprendizagem escolar na dança na infância. Salvador, 2004, 168 f. Dissertação (Mestrado) - Universidade Federal da Bahia (UFBA), 2004.

MARTINS, Janaina Träzel. Os princípios da ressonância vocal na ludicidade dos jogos corpo-voz para formação do ator. Salvador, 2008. 196 f. Tese (Doutorado Escola de Teatro, Universidade Federal da Bahia, 2008.

SPOLIN, Viola. Improvisação para o teatro. São Paulo: Perspectiva, 1987.

SPOLIN, Viola. Jogos teatrais na sala de aula: um manual para o professor.

Tradução Ingrid Dormien Koudela e Eduardo Amos. São Paulo: Perspectiva, 2010.

RAMOS, Enanmar. Angel Viana: a pedagogia do corpo. São Paulo, Summus, 2007.

RANGEL, Lenira. Dicionário Laban. 2. ed. São Paulo: Annablume, 2005.

RANGEL, Lenira. Os temas de movimento de Rudolf Laban (I-II-III-IV-V-VI-

VI VIII): modos de aplicação e referência. São Paulo: Annablume, 2008. (Caderno de corpo e dança).

OSTROWER, Fayga. Criatividade e processo de criação. Petrópolis, RJ: Vozes, 1987. 